\title{
ANALISIS KUALITAS PELAYANAN PENYEDIAAN AIR BERSIH DI UPT AM KOTA METRO
}

\author{
Oleh
}

Oriza Agustin

\begin{abstract}
Basically the implementation unit of a regional government such as UPT (Unit Pelaksana Teknis/Technical Implementation Unit) is assigned a social mission. However, based on observation both in the field and in UPT Air Minum in Metro City, as well as the society as the customers, the following problems are found: the low quality and quantity of clean water supply, and limitation to the continuity of water distribution. The implementation of public service is still interfered by ineffective and inefficient governmental system, as well as incompetent human resources. It can be seen from the society's prevailing dissatisfaction and complaint, both directly and indirectly expressed through mass media. The causes are ineffective procedure, no assurance of time in completion process and in cost, unclear requirements, and unresponsive officials, leading to negative image of the government. To overcome those conditions, improvement is highly requeired in public service sustainability in order to establish a qualified public service. The objective of this study is to understand service quality of UPT Air Minum of Metro City to their customers. Basically, quality implies similar purpose in determining service quality, to be specific. The scope of this study is the service quality of UPT Air Minum of Metro City which is focused on water serving. By using qualitative descriptive method with a single table, data is collected using triangulation technique (observation, interview and documentation). The informants are 15 interviewers and 70 questionnaires informants from the total of 1544 customers. From the research result using interview, observation and documentation, it is found that the service quality of UPT Air Minum of Metro City which is described in terms of product and tangibility, responsiveness, empathy, reliability, assurance may be assumed as qualified. It is supported by single table; Tangible $61.43 \%$, Reliability $72.86 \%$, Responsiveness $90.00 \%$, Assurance $76.79 \%$, Empathy $87.14 \%$. Based on the whole service quality criteria above, it can be concluded that service quality in UPT Air Minum of Metro City is definitely qualified. Thus, the researcher implies that UPT Air Minum of Metro City needs evaluation and that related Department to provide better response to those.
\end{abstract}

Keywords: Service Quality, Tangible, Reliability, Responsiveness, Assurance, and Empathy.

\section{PENDAHULUAN}

Unit pelaksanaan dalam sebuah pemerintah daerah seperti (UPT) pada dasarnya dibebani misi sosial dalam menjalankan usahanya. Namun Dari hasil observasi dilingkup kerja UPT Air Minum Kota Metro dan masyarakat pengguna jasa layanan ditemukan berbagai permasalahan antara lain:

- Persediaan Air bersih yang masih terbatas

- Kualitas air bersih yang masih belum memenuhi standar

- Waktu penyediaan air bersih yang dibatasi pemakaianya

UPT Air Minum selaku bentuk unit pelaksana yang birokrasinya bersentuhan langsung dengan masyarakat (Street Level Beaucracy) tetap harus menjaga keprofesionalitas kinerja pelayanannya. Salah satunya dalam inovasi memformulasikan kebijakan oleh elit politik.

Dalam hubungan dengan pelayanan organisasi, terdapat beberapa penelitian terdahulu yang pernah dilakukan sebelumnya sebagai bahan acuan penelitian. Hasil penelitian yang dilakukan Tjiptono oleh Indiahono (2009:166) menyatakan bahwa kepuasan atau ketidakpuasan pelanggan adalah respon pelanggan terhadap evaluasi ketidaksesuaian yang dirasakan antar harapan sebelumnya atau harapan kinerja lainnya dan kinerja aktual yang dirasakan setelah pemakaian.

Berdasarkan pembahasan tentang kualitas pelayanan unit pelaksana, tentu saja terdapat beragam pendapat seperti dalam penelitian yang dilakukan oleh Duadji (2013:120) bahwa penentuan kualitas suatu pelayanan publik yang bagus atau buruk hanyalah publik yang dilayani itulah dapat menilai. Konsumen pula yang dapat menilai dengan tepat bagaimana kinerja 
Jurnal Al Nidzom, Vol. 3, No. 2, Februrari-Juli 2019

pelayanan publik yang telah diberikan kepada mereka. Kualitas pada hakikatnya merupakan suatu nilai yang dilihat dari sudut pandang mereka yang dilayani dan bukan hasil rekayasa dari mereka yang memberikan pelayanan. Salah satu tolak ukur bagi pelayanan publik yang baik (good service) dengan demikian adalah kemampuannya untuk memenuhi kebutuhan dari setiap individu yang dilayaninya.

\section{Tujuan Penelitian}

Adapun tujuan dari penelitian ini adalah sebagai berikut: Mengetahui kualitas pelayanan UPT AM Kota Metro terhadap masyarakat pengguna jasa layanannya.

\section{TINJAUAN PUSTAKA}

Pasolong (2010:128) Pelayanan adalah aktifitas seorang atau kelompok organisasi baik langsung maupun tidak langsung dalam memenuhi kebutuhan. Monir (2003:16) dalam pasolong (2010:128) mengemukakan proses pemenuhan kebutuhan melalui aktivitas orang lain secara langsung. Menurut Agung Kurniawan dalam Sinambela (2005:5) pelayanan publik diartikan, pemberian layanan (melayani) keperluan orang atau masyarakat yang mempunyai kepentingan pada organisasi itu sesuai dengan aturan pokok dan tata cara yang telah ditetapkan.

Pelayanan publik menurut Sinambela (2005:25) oleh Pasolong (2010:128) adalah setiap kegiatan yang dilakukan oleh pemerintah terhadap sejumlah manusia memiliki kegiatan yang menguntungkan dalam suatu kumpulan atau kesatuan, menawarkan kepuasan meskipun hasilnya tidak terikat pada suatu produk secara fisik.

Penyelenggaraan pelayanan publik merupakan upaya negara untuk memenuhi kebutuhan dasar dan hak-hak sipil setiap warga negara atas barang, jasa, dan pelayanan administrasi yang disediakan oleh penyelenggara pelayanan publik. Di Indonesia, Undang-Undang Dasar 1945 (UUD 1945) mengamanatkan kepada negara agar memenuhi kebutuhan dasar kepada setiap warganya demi kesejahteraannya, sehingga efektivitas suatu sistem pemerintahan sangat ditentukan oleh baik buruknya penyelenggaraan pelayanan publik.

Penyelenggara pelayanan publik di Indonesia adalah semua organ Negara yaitu Pemerintah Pusat, Pemerintah Daerah (Provinsi, Kabupaten, Kota). Dalam hal ini, Pembukaan Undang-Undang Dasar 1945 pun secara tegas menyatakan bahwa salah satu
ISSN : 2614-2570

tujuan didirikan Negara Republik Indonesia adalah untuk memajukan kesejahteraan publik dan mencerdaskan kehidupan bangsa.

Disadari bahwa kondisi penyelenggaraan pelayanan publik masih dihadapkan pada sistem pemerintahan yang belum efektif dan efisien serta kualitas sumber daya manusia aparatur yang belum memadai. Hal ini terlihat dari masih banyaknya keluhan dan pengaduan dari masyarakat baik secara langsung maupun melalui media massa, seperti prosedur yang berbelit-belit, tidak ada kepastian jangka waktu penyelesaian, biaya yang harus dikeluarkan, persyaratan yang tidak transparan, sikap petugas yang kurang responsif dan lain-lain, sehingga menimbulkan citra yang kurang baik terhadap citra pemerintah. Untuk mengatasi kondisi tersebut perlu dilakukan upaya perbaikan kualitas penyelenggaraan pelayanan publik secara berkesinambungan demi mewujudkan pelayanan publik yang berkualitas.

Definisi pelayanan yang berkualitas menurut Osborn dan Gebler (1995) dan Bloom (1981) dalm Pasolong (2010:133) memiliki pengertian bahwa pelayanan tidak prosedural (birokratis), terdistribusi dan terdesentralisasi serta beroreantasi kepada masyarakat atau pelanggan.

Inti pelayanan yang baik dan berkualitas adalah kepedulian terhadap apa yang dibutuhkan

masyarakat. Sehingga yang dimaksud dengan pelayanan yang berkualitas pada UPT AM Kota Metro adalah bagaimana UPT tersebut mampu memiliki respon yang tinggi dalam mendengar, menyerap, dan mengakomodasi kepentingan dan kebutuhan masyarakat.

Kualitas Pelayanan oleh UPT AM Kota Metro akan terwujud apabila apa yang menjadi harapan dan diperolah masyarakat dan bagaimana pelayanan diberikan sesuai pada kenyataaannya.

Zeithaml, Parasuraman dan Berry dalam Pasolong (2010:135) mengungkapkan bahwa penilaian kualitas pelayanan jasa dievaluasi oleh lima dimensi besar yaitu: (1) Reliability (keandalan) atau mengukur kemampuan institusi dalam memberikan jasa yang tepat dan dapat diandalkan untuk konsistensi layanan agar mampu memenuhi syarat validitas; (2) Responsiveness (daya tanggap) yaitu membantu memberikan pelayanan cepat atau ketanggapan institusi dalam memberi layanan dengan segera; (3) Assurance (jaminan) mengukur kemampuan dengan kesopanan karyawan agar timbul rasa percaya atau jaminan pelayanan sebaik mungkin; (4) Empathi atau 


\section{Jurnal Al Nidzom, Vol. 3, No. 2, Februrari-Juli 2019}

kemampuan untuk mengukur pemahaman karyawan terhadap kebutuhan konsumen dalam bentuk perhatian yang diberikan karyawan tersebut untuk memenuhi keinginan customer; dan (5) Tangibility (kasat mata) mengukur penampilan fisik, peralatan yang tersedia, sarana komunikasi untuk pelayanan.

Unit pelaksanaan dalam sebuah pemerintah daerah seperti (UPT) pada dasarnya dibebani misi sosial dalam menjalankan usahanya. Namun Dari hasil observasi dilingkup kerja UPT Air Minum Kota Metro dan masyarakat pengguna jasa layanan ditemukan berbagai permasalahan antara lain:

Persediaan Air bersih yang masih terbatas, Kualitas air bersih yang masih belum memenuhi standar, Waktu penyediaan air bersih yang dibatasi pemakaianya.

UPT Air Minum selaku bentuk unit pelaksana yang birokrasinya bersentuhan langsung dengan masyarakat (Street Level Beaucracy) tetap harus menjaga keprofesionalitas kinerja pelayanannya. Salah satunya dalam inovasi memformulasikan kebijakan oleh elit politik.

Dalam hubungan dengan pelayanan organisasi, terdapat beberapa penelitian terdahulu yang pernah dilakukan sebelumnya sebagai bahan acuan penelitian. Hasil penelitian yang dilakukan Tjiptono oleh Indiahono (2009:166) menyatakan bahwa kepuasan atau ketidakpuasan pelanggan adalah respon pelanggan terhadap evaluasi ketidaksesuaian yang dirasakan antar harapan sebelumnya atau harapan kinerja lainnya dan kinerja aktual yang dirasakan setelah pemakaian.

Berdasarkan pembahasan tentang kualitas pelayanan unit pelaksana, tentu saja terdapat beragam pendapat seperti dalam penelitian yang dilakukan oleh Duadji (2013:120) bahwa penentuan kualitas suatu pelayanan publik yang bagus atau buruk hanyalah publik yang dilayani itulah dapat menilai. Konsumen pula yang dapat menilai dengan tepat bagaimana kinerja pelayanan publik yang telah diberikan kepada mereka. Kualitas pada hakikatnya merupakan suatu nilai yang dilihat dari sudut pandang mereka yang dilayani dan bukan hasil rekayasa dari mereka yang memberikan pelayanan. Salah satu tolak ukur bagi pelayanan publik yang baik (good service) dengan demikian adalah kemampuannya untuk memenuhi kebutuhan dari setiap individu yang dilayaninya.

Sesuai dengan teori Public Good, dimana penanganan jasa dan barang tidak bisa diatur melalui pasar baik dalam produksi, harga dan distribusinya. Dalam
ISSN : 2614-2570

konsumsinya tidak bisa dipisahkan antara pelanggan yang membayar dengan orang yang tidak membayar, kolektif/tidak bisa diketeng, Indiahono (2009:59). Beda halnya dengan air bersih yang tergolong Barang Toll atau Toll Goods yaitu natural resources yang dikonsumsi secara bersama tetapi dapat dipisah antara yang sudah membayar atau tidak (Savas : 2000) dalam Duadji (2013:18).

Barang publik adalah barang yang mudah ditemukan dalam kehidupan bermasyarakat dalam suatu negara. Secara singkat, barang publik merupakan barang yang dapat dikonsumsi siapapun tanpa mempengaruhi manfaat yang diperoleh pihak lain yang juga menginginkan akses terhadap barang publik tersebut. Teori mengenai barang publik disepakati dikembangkan pertama kali oleh seorang ekonom Amerika yang bernama Paul A. Samuelson (19152009).

Dalam karya tulisnya pada tahun 1954 yang berjudul The Pure Theory of Public Expenditure, ia mendefinisikan barang publik atau sebagaimana yang disebut dalam karya tulisnya sebagai "collective consumption good" (barang yang dikonsumsi secara kolektif/bersama-sama), sebagai berikut :

"goods which all enjoy in common in the sense that each individual's consumption of such a good leads to no subtractions from any other individual's consumption of that good".

New Public Management (Manajemen Publik Baru) yang mana menurut Ferlie dalam Keban (2004: 25) oleh pasolong (2010:34) menyebutkan mengenai Orientasi in Search of Exellence yaitu mengutamakan kinerja yang optimal dengan memanfaatkan ilmu pengetahuan, sumber daya manusia dan teknologi. Paradigma ini lebih berfokus kepada manajemen yang responsif terhadap perubahan dan kepuasan pelanggan merupakan bentuk manajemen yang berusaha mengupdate kemajuan bagi perusahaan. Ada pergeseran kearah pemecahan ke unit/ organisasi yang lebih kecil langsung bersentuhan dengan masyarakat sebagai bentuk pelayanan publik yang tidak kaku (Street Level Bireaucracy).

Hal ini dapat dilakukan sebuah manajemen agar mengetahui perkembangan kebutuhan apa saja yang menjadi trend dan selera bagi customer-nya demi

keberlangsungan sebuah perusahaan dalam persaingan bisnis yang kompetitif. Pengoptimalan kinerja perusahaan dilakukan semaksimal mungkin untuk memberikan kepuasan kepada pelanggan. 


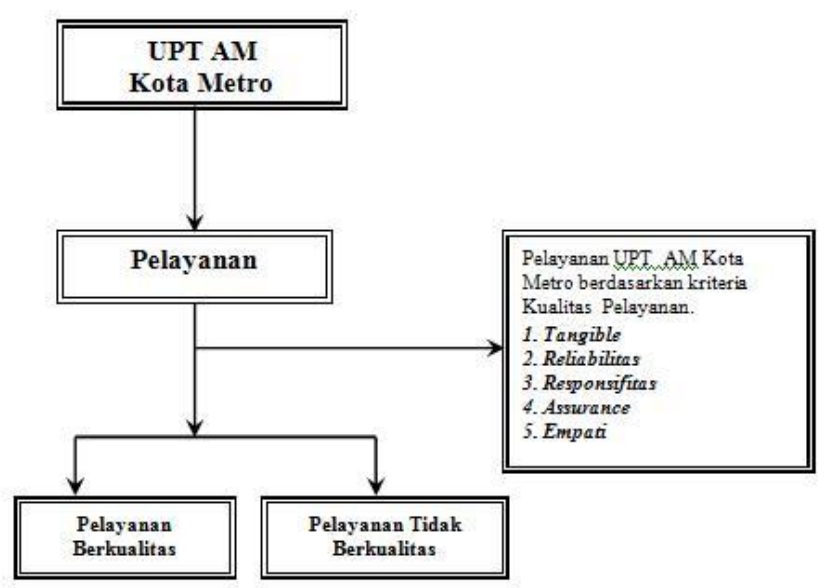

Bagan 2.1 Kerangka Pemikiran

\section{METODOLOGI}

Dalam penelitian ini penulis menggunakan metode penelitian kualitatif dengan tabel tunggal. Menurut Sugiyono (2007:1-2) metode penelitian kualitatif adalah metode penelitian yang digunakan untuk meneliti pada kondisi obyek yang alamiah, (sebagai lawannya adalah eksperimen) dimana peneliti adalah sebagai instrumen kunci, teknik pengumpulan data dilakukan secara trianggulasi (gabungan), analisis data bersifat induktif, dan hasil penelitian kualitatif lebih menekankan makna dari pada generalisasi.

Penggunaan metode kualitatif dilaksanakan sesuai dengan karakteristik yang ada yaitu secara langsung terlibat di lokasi penelitian. Pendekatan ini menekankan akan pentingnya pemahaman tingkah laku menurut pola berfikir dan bertindak. Subjek kajian dengan analisa secara induktif, mengarahkan sasaran penelitiannya pada usaha menemukan teoriteori dasar dan lebih mementingkan segi "proses" daripada "hasil". Selain itu penelitian ini bersifat deskriptif, yaitu suatu jenis penelitian yang mengungkapkan permasalahan mengenai apa adanya (dassolen) sesuai dengan kenyataan yang ada di lokasi penelitian.

Menurut Nazir (2003:54-55) metode deskriptif adalah suatu metode dalam meneliti status kelompok manusia, suatu objek, suatu set kondisi, suatu sistem pemikiran, ataupun suatu kelas peristiwa pada masa sekarang. Tujuan dari penelitian deskriptif ini adalah untuk membuat deskripsi, gambaran atau lukisan secara sistematis, faktual dan akurat mengenai faktafakta, sifat-sifat serta hubungan antar fenomena yang diselidiki.

Melalui penelitian metode kualitatif akan diperoleh data yang sebenarnya (alami) dan digunakan untuk mengkaji masalah penelitian secara mendalam untuk mencapai suatu pemahaman. Adapun yang menjadi alasan penulis menggunakan metode ini adalah bahwa metode kualitatif dianggap lebih mudah menyesuaikan apabila berhadapan dengan kenyataan sosial yang sebelumnya tidak diduga dan dapat pula menyajikan secara langsung hubungan antara penulis dengan responden serta metode ini lebih peka terhadap segala perubahan dan pola-pola nilai yang berlaku.

Penulis menempatkan manusia sebagai subyek utama dalam peristiwa sosial/budaya. Artinya adalah pemikiran bukan untuk diarahkan pada objeknya melainkan lebih difokuskan pada subjek yang akan diamati dalam penelitian seperti dijelaskan oleh Novita Tresiana (2013:33).

Sumber data utama dalam penelitian kualitatif adalah kata-kata dan tindakan serta selebihnya adalah data tambahan seperti tabel tunggal, dokumen dan lainlain.

Berdasarkan Peraturan Daerah Kota Metro Nomor 25 Tahun 2000 tentang pemekaran Kelurahan dan Kecamatan di Kota Metro, wilayah administrasi pemerintah Kota Metro dimekarkan menjadi 5 kecamatan yang meliputi 22 kelurahan. Luas wilayah Kota Metro adalah 68,74 km2. Dari total jumlah pelanggan sebanyak 1544 orang, diambil sampel untuk informan wawancara sebanyak 15 orang dengan rincian informan dari Metro Pusat sebanyak 5 orang $(0.32 \%)$ Metro Barat sebanyak 4 orang $(0.26 \%)$ Metro Timur 6 Orang $(0.39 \%)$ untuk masing-masing kecamatan. Untuk metro utara dan metro selatan status pelanggan belum aktif. Sedangkan untuk informan kuesioner sebanyak 70 orang dengan rincian Pelanggan metro pusat sebanyak 29 orang $(1.88 \%)$, Pelanggan dari Metro Barat Sebanyak 23 orang (1.49\%) dan pelanggan dari Metro Timur sebanyak 18 orang $(1.17 \%)$ untuk masing-masing kecamatan.

Pengambilan sampel dalam pelitian ini didasarkan atas pertimbangan purposive sample yaitu penetapan sampel berdasarkan pada apa yang menjadi tujuan kemanfaatannya. Maka kekuatan sampel purposif terletak pada kasus studi yang mendalam sehingga penulis bisa memilih informan yang mendekati isu sentral dalam penelitiannya Tresiana ( 2013:82)

Sampel sendiri merupakan istilah yang lazim dalam penelitian kuantitatif, sedangkan dalam penelitian kualitatif sumber datanya berupa informan. Maka dalam penelitian deskriptif kualitatif ini, peneliti akan 


\section{Jurnal Al Nidzom, Vol. 3, No. 2, Februrari-Juli 2019}

membutuhkan informan sesuai dengan istilah convenience sampling atau no probalitas sampel sesuai dengan persyaratan sebagai berikut; 1) representativeness dari setting, individu dan aktifitas yang dipilih penulis; 2) menggambarkan secara memadai heterogenitas populasi; 3 ) informan sengaja dipilih untuk menguji kasus terhadap teori yang dijadikan acuan; 4) menjadi perbandingan dalam menggambarkan alasan perbedaan antara setting dan individu.

Penentuan sampel dapat dilakukan dengan menggunakan rumus Slovin (Riduwan, 2010), yaitu :

$$
\mathrm{n}=\frac{N}{\left(1+N(e)^{2}\right)}
$$

$\mathrm{n}=$ ukuran sampel

$N=$ populasi (jumlah pelanggan aktif UPT AM di Kota Metro)

$e=$ tingkat presisi yang ditetapkan

Dalam penelitian ini digunakan tingkat presisi ketidaktelitian $10 \%$

Sehingga ukuran sampel dalam penelitian ini yaitu :

$$
1.544
$$

$\mathrm{n}=$

$$
\left(1+1.544(\mathrm{e})^{2}\right)
$$

$\mathrm{n}=70,186$

dibulatkan menjadi 70 sampel.

Jadi, dalam penelitian ini terdapat 70 pelanggan yang dijadikan sampel, yang kemudian disebut sebagai responden. Untuk penentuan responden digunakan teknik disproportionate stratified random sampling. Teknik ini digunakan untuk menentukan jumlah sampel, bila populasi berstrata tetapi kurang proporsinal (Sugiyono, 2014).

Dalam mendeskripsikan penelitian kualitatif ini, peneliti menggunakan tipe Opportunistic sampling (sample secara tiba-tiba), yaitu sample yang menggambarkan kasus yang diketahui dilapangan dengan mewawancarai orang terkait tanpa dikenal
ISSN : 2614-2570

sebelumnya. Walaupun tidak ada aturan secara khusus untuk penentuan jumlah informan namun jumlah informan tergantung dari apa yang ingin diketahui peneliti, Tresiana (2013:85). Dalam penelitian ini, peneliti menarik informan dari jumlah pelanggan air bersih UPT Kota Metro ditentukan sebanyak 70 informan kuesioner dan 15 informan interview dari pelanggan aktif yang menggunakan jasa pelayanan UPT AM Kota Metro secara acak.

Dengan demikian sumber data primer berupa

informasi dan wawancara dengan masyarakat di lokasi penelitian sebagai sumber utama yang menjadi sumber informasi dan objek yang dijadikan sumber data dari penelitian ini. Masyarakat Kota Metro sebagai pelanggan air bersih serta wawancara dari beberapa pejabat pemerintah Kota Metro yang terkait;

1. Kepala UPT AM Kota Metro.

2. Kepala Dinas Pekerjaan Umum dan Perumahan Kota Metro.

\section{Petugas dan karyawan UPT AM Kota Metro.}

Instrumen penelitian adalah alat yang digunakan untuk mengumpulkan data. Dalam penelitian dengan metode kualitatif pengumpulan data yang lebih banyak tergantung pada peneliti sendiri sebagai alat pengumpul data. Peneliti sebagai instumen penelitian membuat pedoman pengamatan dan pedoman wawancara untuk mendapatkan data primer, sedangkan isian blangko kuesioner berupa table tunggal sebagai penguat deskripsi dari hasil wawancara. Sehingga data penelitian lebih jelas. Hasil dari ketiganya digunakan peneliti sebagai data penelitian.

Penelitian kualitatif harus mengungkap kebenaran yang objektif. Karena itu keabsahan data dalam sebuah penelitian kualitatif sangat penting. Melalui keabsahan data kredibilitas (kepercayaan) penelitian kualitatif dapat tercapai. Dalam penelitian ini untuk mendapatkan keabsahan data dilakukan dengan teknik triangulasi. Dalam memenuhi keabsahan data penelitian ini dilakukan triangulasi dengan sumber. Menurut Patton 1980 dalam Tresiana (2013:147). Triangulasi dengan sumber berarti membandingkan dan mengecek balik derajat kepercayaan suatu informasi yang diperoleh melalui waktu dan alat yang berbeda dalam penelitian kualitatif (Moleong, 2007:29). Triangulasi sumber yang dilaksanakan pada penelitian ini yaitu membandingkan hasil wawancara, kuesioner tabel tunggal dengan isi dokumen yang berkaitan. 


\section{HASIL DAN PEMBAHASAN}

Informan adalah pihak-pihak yang dijadikan sumber data dalam sebuah penelitian. Sedangkan deskripsi informan diartikan sebagai gambaran tentang karakteristik informan. Deskripsi informan ini berkaitan dengan identitas informan (usia dan jenis kelamin), atau latar belakang kehidupan informan (latar belakang pendidikan dan latar belakang pekerjaan). Penggambaran deskripsi informan dalam penelitian ini bertujuan untuk memberikan gambaran dan tambahan pengetahuan mengenai keberagaman informan yang terdapat di Kecamatan Samigaluh. Pendeskripsian informan dalam penelitian ini tidak berkorelasi secara langsung terhadap hasil penelitian karena tabel dan grafik yang disajikan dalam penelitian ini ditampilkan secara umum atau mencakup keseluruhan karakteristik informan.

\section{Kualitas Pelayanan UPT Air Minum Kota Metro}

\section{Tangible ( Prasarana Fisik )}

Menurut Zeithaml, Parasuraman dan Berry dalam Pasolong, (2010:135) Tangibility (kasat mata) adalah melihat kriteria pelayanan melalui penampilan fisik, peralatan yang tersedia, sarana komunikasi untuk pelayanan. Dalam penelitian ini kriteria tangible dideskripsikan melalui;

- Kenyamanan di lingkungan kerja pelayanan

- Produk layanan (kualitas, kuantitas dan kontinuitas distribusi air, atribut seperti; pipa, meteran, dll)

- Sarana pelayanan (loket pelayanan untuk pengaduan dan keluhan, kotak saran, pembayaran rekening, dll)

\section{- Penampilan dan pelayanan pegawai}

Untuk memudahkan pengguna jasa, UPT AM Kota Metro berusaha memenuhi hal tersebut diatas dengan menyediakan berbagai macam fasilitas yang menunjang.

\begin{tabular}{|c|c|c|c|c|c|c|c|c|c|c|c|}
\hline \multirow{3}{*}{ No } & \multirow{3}{*}{$\begin{array}{l}\text { PERTANYAAN } \\
\text { PertanyaanNo } 12\end{array}$} & \multicolumn{8}{|c|}{ KRITERIA TANGIBLE } & \multirow{2}{*}{\multicolumn{2}{|c|}{$\begin{array}{c}\text { TOTAL } \\
\text { INFORMAN }\end{array}$}} \\
\hline & & \multicolumn{2}{|c|}{$\begin{array}{l}\text { TIDAK } \\
\text { BAIK }\end{array}$} & \multicolumn{2}{|c|}{$\begin{array}{c}\text { KURANG } \\
\text { BAIK }\end{array}$} & \multicolumn{2}{|c|}{ BAIK } & \multicolumn{2}{|c|}{$\begin{array}{c}\text { SANGAT } \\
\text { BAIK }\end{array}$} & & \\
\hline & & 2 & $2.86 \%$ & 28 & $40.00 \%$ & 35 & $50.00 \%$ & 5 & $7.14 \%$ & 70 & $100 \%$ \\
\hline 2 & PertanyaanNo 13 & 3 & $4.29 \%$ & 25 & $35.71 \%$ & 33 & $47.14 \%$ & 9 & $12.86 \%$ & 70 & $100 \%$ \\
\hline 3 & PertanyaanNo 14 & 1 & $1.43 \%$ & 22 & $31.43 \%$ & 37 & $52.86 \%$ & 10 & $14.29 \%$ & 70 & $100 \%$ \\
\hline & Rata-Rata & 2 & $2.86 \%$ & 25 & $35.71 \%$ & 35 & $50.00 \%$ & 8 & $11.43 \%$ & 70 & $100 \%$ \\
\hline
\end{tabular}

Tabel 4.8

Kriteria Pelayanan Tangible
Dari tabel di atas, terdapat 2 Informan (2.86\%) menggambarkan bahwa kualitas pelayanan UPT AM Kota Metro dalam hal produk layanan, sarana, dan kenyamanan pelayanan tidak baik, Sebanyak 25 Informan (35.71\%) menggambarkan bahwa kualitas pelayanan UPT AM Kota Metro dalam hal produk layanan, sarana, dan kenyamanan pelayanan kurang baik. Kemudian sebanyak 35 Informan (50.00\%) menggambarkan bahwa kualitas pelayanan UPT AM Kota Metro dalam hal produk layanan, sarana, dan kenyamanan pelayanan baik dan 8 orang Informan (11.43\%) menggambarkan bahwa kualitas pelayanan UPT AM Kota Metro dalam hal produk layanan, sarana, dan kenyamanan pelayanan tidak baik. Dari grafik tersebut dapat kita lihat bahwa mayoritas Informan $(50.00 \%)$ menggambarkan bahwa kualitas pelayanan UPT AM Kota Metro dalam hal produk layanan, sarana, dan kenyamanan pelayanan baik.

\section{Reliabilitas}

Reliabilitas adalah kem ampuan menyelenggarakan pelayanan terhadap pelanggan secara akurat. Dengan reliabilitas yang tinggi akan menciptakan kinerja yang baik dan nantinya terwujud kualitas pelayanan yang baik, sehingga apa yang menjadi harapan masyarakat tentang pelayanan akan sesuai dengan harapannya. Adapun kriteria reliabilitas dideskripsikan melalui hal berikut;

- Keadilan dalam mendapatkan pelayanan

- Kewajaran biaya (kesesuaian biaya yang dibayarkan dan ditetapkan)

- Ketepatan waktu dengan jadwal pelayanan

- Prosedur menjadi pelanggan baru

\begin{tabular}{|c|c|c|c|c|c|c|c|c|c|c|c|}
\hline \multirow{3}{*}{$\begin{array}{r}\text { No } \\
1 \\
\end{array}$} & \multirow{3}{*}{$\begin{array}{l}\text { PERTANYAAN } \\
\text { PertanyaanNo } 8\end{array}$} & \multicolumn{8}{|c|}{ KRITERIA RELIABILITAS } & \multirow{2}{*}{\multicolumn{2}{|c|}{$\begin{array}{c}\text { TOTAL } \\
\text { INFORMAN }\end{array}$}} \\
\hline & & \multicolumn{2}{|c|}{$\begin{array}{l}\text { TIDAK } \\
\text { BAIK }\end{array}$} & \multicolumn{2}{|c|}{$\begin{array}{c}\text { KURANG } \\
\text { BAIK }\end{array}$} & \multicolumn{2}{|c|}{ BAIK } & \multicolumn{2}{|c|}{$\begin{array}{c}\text { SANGAT } \\
\text { BAIK }\end{array}$} & & \\
\hline & & 4 & $5.71 \%$ & 16 & $22.86 \%$ & 41 & $58.57 \%$ & 9 & $12.86 \%$ & 70 & $100 \%$ \\
\hline 2 & PertanyaanNo 9 & 3 & $4.29 \%$ & 13 & $18.57 \%$ & 37 & $52.86 \%$ & 17 & $24.29 \%$ & 70 & $100 \%$ \\
\hline 3 & Pertanyaan No 10 & 3 & $4.29 \%$ & 18 & $25.71 \%$ & 44 & $62.86 \%$ & 5 & $7.14 \%$ & 70 & $100 \%$ \\
\hline 4 & PertanyaanNo 11 & 2 & $2.86 \%$ & 17 & $24.29 \%$ & 40 & $57.14 \%$ & 11 & $15.71 \%$ & 70 & $100 \%$ \\
\hline & Rata-Rata & 3 & $4.29 \%$ & 16 & $22.86 \%$ & 41 & $57.86 \%$ & 11 & $15.00 \%$ & 70 & $100 \%$ \\
\hline
\end{tabular}

Tabel 4.9

Kriteria Pelayanan Reliabilitas

Dari tabel di atas, terdapat 3 Informan (4.29\%) menggambarkan bahwa kualitas pelayanan UPT AM Kota Metro dalam hal keadilan, kewajaran dan kesesuaian biaya serta ketepatan waktu pelayanan 
Jurnal Al Nidzom, Vol. 3, No. 2, Februrari-Juli 2019

tidak baik. Sebanyak 16 Informan (22.86\%) menggambarkan bahwa kualitas pelayanan UPT AM Kota Metro dalam hal keadilan, kewajaran dan kesesuaian biaya serta ketepatan waktu pelayanan kurang baik. Kemudian sebanyak 41 Informan (57.86\%) menggambarkan bahwa kualitas pelayanan pada UPT AM Kota Metro dalam hal keadilan, kewajaran dan kesesuaian biaya serta ketepatan waktu pelayanan baik dan 11 orang Informan (15.00\%) menggambarkan bahwa kualitas pelayanan UPT AM Kota Metro dalam hal keadilan, kewajaran dan kesesuaian biaya serta ketepatan waktu pelayanan tidak baik. Dari tabel tersebut dapat kita lihat bahwa mayoritas Informan (57.86\%) menggambarkan bahwa kualitas pelayanan UPT AM Kota Metro dalam hal keadilan, kewajaran dan kesesuaian biaya serta ketepatan waktu pelayanan baik.

\section{Responsifitas}

Responsifitas yang dimaksud dalam penelitian ini adalah kemampuan UPT AM Kota Metro beradaptasi terhadap situasi yang berubah-ubah sesuai dengan aktivitas organisasi dan masyarakat dalam mewujudkan suatu pelayanan yang baik sesuai dengan harapan dan aspirasi masyarakat demi

pencapaian tujuan yang telah ditentukan. Responsifitas sangat diperlukan dalam pelayanan kepada masyarakat karena merupakan bukti kemampuan organisasi untuk memenuhi kebutuhan masyarakat. Responsifitas yang tinggi akan menunjukkan dan menciptakan kinerja yang baik dan kualitas pelayanan yang baik. Adapuin kriteria ini dapat dideskripsikan melalui;

- Kemampuan, kecepatan, kesopanan, keramahan pegawai dalam memberikan pelayanan.

- Perhatian pegawai memadai secara administratif dan teknis.

- Kemudahan dan tanggapan akses pengaduan melalui telepon.

Dalam memberikan pelayanan kepada masyarakat UPT AM Kota Metro, tentunya tidak lepas dari ketidak puasan pelanggan akibat pelayanan yang diberikan tidak sesuai dengan keinginan dan aspirasi masyarakat pengguna jasa. Untuk mengatasi hal tersebut UPT AM memberikan respon baik yaitu dengan membuka pelayanan keluhan, baik itu menyangkut keluhan administrasi maupun keluhan gangguan teknik. Permasalahan administrasi yang sering timbul adalah yang berkaitan dengan masalah rekening air, seperti berikut ini : a. Rekening air yang melonjak tinggi

b. Tunggakan air yang ditagihkan sekaligus

c. Kesalahan rekening

d. Pelayanan buka kembali

e. Pelayanan balik nama dan Pindah Alamat

f. Permintaan tutup sementara

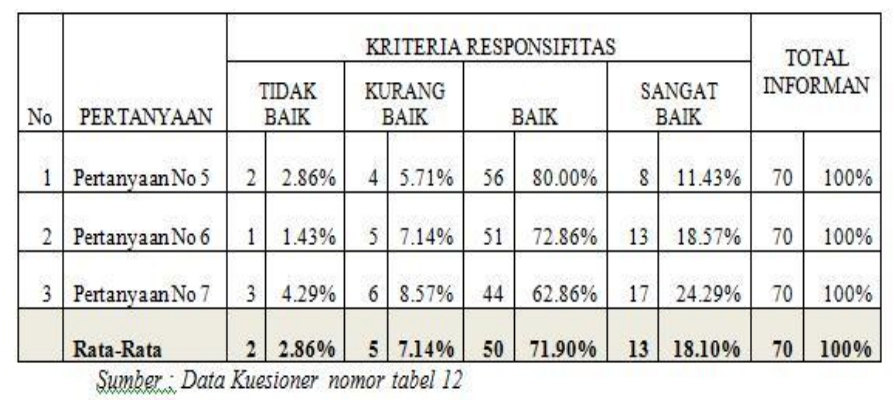

Tabel 4.10

Kriteria Pelayanan Responsifitas

Dari tabel di atas, terdapat 2 Informan (2.86\%) menggambarkan bahwa kualitas pelayanan UPT AM Kota Metro dalam kemampuan organisasi untuk memenuhi kebutuhan masyarakat tidak baik,. Sebanyak 5 Informan (7.14\%) menggambarkan bahwa kualitas pelayanan UPT AM Kota Metro dalam hal kemampuan organisasi untuk memenuhi kebutuhan masyarakat kurang baik. Kemudian sebanyak 50 Informan (71.40\%) menggambarkan bahwa kualitas pelayanan UPT AM Kota Metro dalam hal kemampuan organisasi untuk memenuhi kebutuhan masyarakat baik dan 13 orang Informan (18.10\%) menggambarkan bahwa kualitas pelayanan UPT AM Kota Metro dalam hal kemampuan organisasi untuk memenuhi kebutuhan masyarakat tidak baik.

Dari tabel tersebut dapat kita lihat bahwa mayoritas Informan (71.40\%) menggambarkan bahwa kualitas pelayanan UPT AM Kota Metro dalam hal kemampuan organisasi untuk memenuhi kebutuhan masyarakat pelayanan sudah baik.

\section{Assurance (Jaminan)}

Penjaminan akan kualitas pelayanan yang baik dari segi pelayanan jasa (tanggung jawab dan kemampuan untuk meyakinkan pelanggan) dan distribusi air bersih perlu diperhatikan oleh UPT AM Kota Metro sebagai kriteria kualitas pelayanan yang baik. Adanya jaminan dari kegiatan pengawasan dan pengamatan daripada pelaksanaan seluruh kegiatan UPT AM Kota Metro telah menjamin supaya pelayanan berupa sikap ramah dan memuaskan dari para pegawai akan memberikan rasa kepercayaan dari masyarakat 
Jurnal AI Nidzom, Vol. 3, No. 2, Februrari-Juli 2019

sebagai pengguna layanan. Rasa percaya dari jaminan serta tanggung jawab pegawai akan dideskripsikan sebagai kualitas pelayanan yang baik. Berikut deskripsi dari kriteria ini dapat dilihat melalui;

- Kemudahan prosedur menjadi pelanggan baru, kejelasan dan kepastian petugas pelayanan, kedisiplinan dan tanggung jawab terhadap keamanan pelayanan.

- Profesionalitas pegawai pada jam kerja.

- Kesesuaian pelayanan di kantor dengan pelayanan teknis di rumah masyarakat.

- Kesesuaian jumlah data perhitungan dengan kondisi sebenarnya.

\begin{tabular}{|c|c|c|c|c|c|c|c|c|c|c|c|}
\hline \multirow[b]{2}{*}{ No } & \multirow[b]{2}{*}{ PERTANYAAN } & \multicolumn{8}{|c|}{ KRITERIA ASSURANCE } & \multirow{2}{*}{\multicolumn{2}{|c|}{$\begin{array}{c}\text { TOTAL } \\
\text { INFORMAN }\end{array}$}} \\
\hline & & \multicolumn{2}{|c|}{$\begin{array}{l}\text { TIDAK } \\
\text { BAIK }\end{array}$} & \multicolumn{2}{|c|}{$\begin{array}{c}\text { KURANG } \\
\text { BAIK }\end{array}$} & \multicolumn{2}{|r|}{ BAIK } & \multicolumn{2}{|c|}{$\begin{array}{l}\text { SANGAT } \\
\text { BAIK }\end{array}$} & & \\
\hline 1 & PertanyaanNo 1 & 3 & $4.29 \%$ & 15 & $21.43 \%$ & 50 & $71.43 \%$ & 2 & $2.86 \%$ & 70 & $100 \%$ \\
\hline 2 & Pertanyaan No 2 & 1 & $1.43 \%$ & 12 & $17.14 \%$ & 47 & $67.14 \%$ & 10 & $14.29 \%$ & 70 & $100 \%$ \\
\hline 3 & PertanyaanNo 3 & 4 & $5.71 \%$ & 16 & $22.86 \%$ & 44 & $62.86 \%$ & 6 & $8.57 \%$ & 70 & $100 \%$ \\
\hline 4 & Pertanyaan No 4 & 4 & $5.71 \%$ & 10 & $14.29 \%$ & 51 & $72.86 \%$ & 5 & $7.14 \%$ & 70 & $100 \%$ \\
\hline & Rata-Rata & 3 & $4.29 \%$ & 13 & $18.93 \%$ & 48 & $68.57 \%$ & 5.8 & $8.21 \%$ & 70 & $100 \%$ \\
\hline
\end{tabular}

Tabel 4.11

Kriteria Pelayanan Assurance

Dari tabel di atas terdapat 3 Informan (4.29\%) menggambarkan bahwa kualitas pelayanan UPT AM Kota Metro dalam memberikan rasa percaya dari jaminan serta tanggung jawab pegawai untuk memenuhi kebutuhan masyarakat tidak baik,. Sebanyak 13 Informan (18.93\%) menggambarkan bahwa kualitas pelayanan UPT AM Kota Metro dalam memberikan rasa percaya dari jaminan serta tanggung jawab pegawai untuk memenuhi kebutuhan masyarakat kurang baik. Kemudian sebanyak 48 Informan (68.57\%) menggambarkan bahwa kualitas pelayanan UPT AM Kota Metro dalam memberikan rasa percaya dari jaminan serta tanggung jawab pegawai untuk memenuhi kebutuhan masyarakat baik dan 6 orang Informan (8.21\%) menggambarkan bahwa kualitas pelayanan UPT AM Kota Metro dalam memberikan rasa percaya dari jaminan serta tanggung jawab pegawai untuk memenuhi kebutuhan masyarakat tidak baik.

Dari tabel tersebut dapat kita lihat bahwa mayoritas Informan (68.57\%) menggambarkan bahwa kualitas pelayanan UPT AM Kota Metro dalam memberikan rasa percaya dari jaminan serta tanggung jawab pegawai untuk memenuhi kebutuhan masyarakat sudah baik.

ISSN : 2614-2570

\section{Empati}

Dalam melayani kebutuhan konsumen UPT AM Kota Metro harus memiliki kepekaan secara emosional dan psikologis atas apa yang menjadi kebutuhan dan keluhan dari setiap masyarakat pengguna jasanya. Dalam hal ini pegawai UPT AM Kota metro diharapkan mampu mengenali keluhan masyarakat seperti pada bagian, pelayanan langganan dan mengurus penagihan rekening, pengelolaan data langganan dan pengecekan ke rumah. Kriteria ini dapat dideskripsikan dari;

- Kemampuan mengenali kebutuhan masyarakat

- Perbedaan sikap pegawai atau dikrimintif dalam pelayanan (karena ekonomi, kedekatan kekeluargaan, status sosial, sikap masyarakat ketika datang.)

- Kedekatan secara emosional dengan pelanggan (empati)

\begin{tabular}{|c|c|c|c|c|c|c|c|c|c|c|c|}
\hline \multirow{3}{*}{$\begin{array}{c}\mathrm{N}_{0} \\
1 \\
\end{array}$} & \multirow{3}{*}{$\begin{array}{l}\text { PERTANYAAN } \\
\text { PertanyaanNo } 15 \\
\end{array}$} & \multicolumn{8}{|c|}{ KRITERIA EMPATI } & \multirow{2}{*}{\multicolumn{2}{|c|}{$\begin{array}{l}\text { TOTAL } \\
\text { INFORMAN }\end{array}$}} \\
\hline & & \multirow{2}{*}{\multicolumn{2}{|c|}{\begin{tabular}{c|c|}
\multicolumn{1}{c|}{ TIDAK } \\
\multicolumn{2}{c|}{ BAIK } \\
2 & $2.86 \%$ \\
\end{tabular}}} & \multicolumn{2}{|c|}{$\begin{array}{c}\text { KURANG } \\
\text { BAIK }\end{array}$} & \multicolumn{2}{|c|}{ BAIK } & \multicolumn{2}{|c|}{$\begin{array}{c}\text { SANGAT } \\
\text { BAIK }\end{array}$} & & \\
\hline & & & & 7 & $10.00 \%$ & 58 & $82.86 \%$ & 3 & $4.29 \%$ & 70 & $100 \%$ \\
\hline 2 & Pertanyaan No 16 & 3 & $4.29 \%$ & 9 & $12.86 \%$ & 46 & $65.71 \%$ & 12 & $17.14 \%$ & 70 & $100 \%$ \\
\hline 3 & Pertanyaan No 17 & 1 & $1.43 \%$ & 5 & $7.14 \%$ & 61 & $87.14 \%$ & 3 & $4.29 \%$ & 70 & $100 \%$ \\
\hline 4 & PertanyaanNo 18 & 2 & $2.86 \%$ & 8 & $11.43 \%$ & 50 & $71.43 \%$ & 10 & $14.29 \%$ & 70 & $100 \%$ \\
\hline & Rata-Rata & 2 & $2.86 \%$ & 7.3 & $10.36 \%$ & 54 & $76.79 \%$ & 7 & $10.00 \%$ & 70 & $100 \%$ \\
\hline
\end{tabular}

Tabel 4.12

Kriteria Pelayanan Empati

Dari tabel di atas, terdapat 2 Informan $(2,86 \%)$ menggambarkan bahwa kualitas pelayanan UPT AM Kota Metro dalam kemampuan mengenali keluhan masyarakat tidak baik,. Sebanyak 7 Informan $(10,36 \%)$ menggambarkan bahwa kualitas pelayanan UPT AM Kota Metro dalam hal kemampuan

mengenali keluhan masyarakat kurang baik. Kemudian sebanyak 54 Informan (76.79\%) menggambarkan bahwa kualitas pelayanan UPT AM Kota Metro dalam hal kemampuan mengenali keluhan masyarakat baik dan 7 orang Informan $(10.00 \%)$ menggambarkan bahwa kualitas pelayanan UPT AM Kota Metro dalam hal kemampuan mengenali keluhan masyarakat tidak baik.

Dari tabel tersebut dapat kita lihat bahwa mayoritas Informan (76.79\%) menggambarkan bahwa kualitas 
pelayanan UPT AM Kota Metro dalam hal kemampuan mengenali keluhan masyarakat pelayanan baik.

\section{KESIMPULAN DAN SARAN Kesimpulan}

Berdasarkan hasil penelitian, observasi lapangan, dan pembahasan tentang Analisis Kualitas Pelayanan UPT Air Minum Kota Metro dalam Penyediaan Air Bersih, maka dapat disimpulkan bahwa: Analisis Kualitas Pelayanan UPT Air Minum Kota Metro dalam Penyediaan Air Bersih difokuskan pada kriteria kualitas pelayanan publik sebagai berikut; Tangible (Prasarana Fisik), Reliabilitas (Akurat),

Responsifitas (Daya Tanggap), Assurance (Jaminan/Kepastian) dan Empati (Rasa/Kedekatan Emosi) pegawai UPT Air Minum Kota Metro terhadap masyarakat pengguna jasa pelayanan publik sudah berkualitas.

Berdasarkan hasil penelitian wawancara dapat diketahui kualitas pelayanan UPT AM Kota Metro dalam hal produk layanan, sarana, dan kenyamanan pelayanan baik diperkuat hasil kuesioner dengan jumlah presentase $61.43 \%$ menyatakan pelayanan tersebut sudah berkualitas, kualitas pelayanan UPT AM Kota Metro dalam hal kejelasan prosedur pelanggan baru, keakuratan tarif, kewajaran dan keadilan biaya bagi masyarakat tergolong kurang mampu sudah baik sesuai hasil kuesioner dengan jumlah presentase $76,79 \%$ menyatakan pelayanan tersebut sudah berkualitas. Kualitas pelayanan UPT AM Kota Metro dalam hal perhatian serius dan memadai dalam pelayanan adminsitratif serta teknis,

kecepatan dalam menanggulangi pengaduan gangguan, kesopanan serta keramahan pegawai sudah baik sesuai hasil kuesioner dengan jumlah presentase 90,00\% menyatakan pelayanan tersebut sudah berkualitas. Kualitas pelayanan UPT Air Minum Kota Metro dalam menjamin mutu pelayanan, kejelasan bagi pelanggan baru, profesionalitas kerja pegawai, kepastian biaya dan kualitas air sudah baik sesuai hasil kuesioner dengan jumlah persentase $72,86 \%$ menyatakan pelayanan tersebut sudah berkualitas. Kualitas pelayanan UPT Air Minum Kota Metro dalam hal merasakan kebutuhan masyarakat, kedekatan emosional dan kesabaran mengahadapi semua pelanggan baik yang tidak dikenal, tanpa membedakan status sosial dan ekonomi sudah baik, sesuai dengan hasil kuesioner dengan jumlah presentase $87,14 \%$ menyatakan pelayanan tersebut sudah berkualitas. Dari seluruh kriteria kualitas pelayanan diatas secara keseluruhan maka dapat disimpulkan kualitas pelayanan di UPT AM Kota Metro berkualitas..

\section{Saran}

Berdasarkan hasil penelitian, maka peneliti dapat memberikan saran- saran untuk dapat memaksimalkan Kualitas Pelayanan UPT Air Minum Kota Metro sebagai berikut;

1. Perlunya evaluasi dan tindak lanjut dari UPT AM Kota Metro terhadap keluhan masyarakat yang berkaitan dengan sarana produk layanan berupa kualitas, kuantitas dan kontinuitas pelayanan penyediaan air bersih agar masyarakat lebih percaya dalam menggunakan air bersih dari UPT AM Kota Metro.

2. Agar dinas terkait diharapkan lebih memberikan perhatian terhadap kendala atas kriteria pelayanan yang berkaitan dengan

- Jaminan (Assurance) berupa sosialisasi kemasyarakat mengenai kualitas air berupa surat jaminan kelayakan uji air bersih dari dinas kesehatan Kota Metro.

- Kontinuitas penyediaan air bersih (Tangible) yang dihadapi UPT AM Kota Metro agar jam operasional pelayanan tidak terbatas waktu tertentu saja.

- Responsifitas terhadap aspirasi masyarakat yang berkaitan dengan perubahan atau keinginan masyarakat berupa pelayanan yang diberikan UPT AM Kota Metro.

- Daya Tanggap (Empati) secara emosional terhadap aspirasi masyarakat yang berkaitan dengan perubahan atau keinginan masyarakat berupa pelayanan yang diberikan UPT AM Kota Metro

- Keakurantan, Kewajaran (Reliabilitas) antara biaya yang ditetapkan dengan kemampuan masyarakat dalam mendapatkan pelayanan dari UPT AM Kota Metro.

\section{DAFTAR PUSTAKA}

Aminudin, 1995, Kinerja PDAM Kota Pontianak, Tesis tidak dipublikasikan, Magister Administrasi Publik, Universitas Gadjah Mada, Yogyakarta.

Bastian, Indra \& Soepriyanto, Gatot, 2002, Sistem Akuntansi Sektor Publik, Salemba Empat, Jakarta

BPS, Provinsi Lampung, Water Supply Statistics of 
Jurnal Al Nidzom, Vol. 3, No. 2, Februrari-Juli 2019

Lampung 2011, Lampung

Bungin, Burhan, 2010, Metodologi Penelitian Kuantitatif, Kencana Prenada Media Group, Jakarta

Duadji, Noverman. 2013. Manajemen Pelayanan Publik (Wacana Konsep Teori dan Problema Pelayanan Publik), Penerbit Lembaga Penelitian Unila, Bandar Lampung

Dwiyanto, Agus. 1995. Penilaian Kinerja Organisasi Publik, Makalah disampaikan pada Seminar Kinerja Organisasi Publik, Fisipol UGM, Yogyarta.

Dwiyanto, Agus \& Kusumasari, 2001, Policy Brief :

Kinerja Pelayanan Publik, Edisi 1,2,3 \&4/PB/2001, Pusat Studi Kebijakan dan Kependudukan, Yogyakarta.

Echlos, Jhon \& Shadily, 1992, Kamus InggrisIndoesia, Gramedia, Jakarta

Effendy, Sofyan, 1993, Pelayanan Publik di Indonesia, Prisma, Jakarta

Indiahono, Dwiyanto, 2009, Kebijakan Publik Berbasis Dynamic Policy Analisys, Gava Media, Yogyakarta

Indrabuana, Dwi, 2000, Efektivitas Pelayanan Pemerintah Kecamatan, Skripsi tidak dipublikasikan, Fisipol Universitas Gadjah Mada, Yogyakarta.

Karjadi, 1989, Kepemimpinan, Karya Nusantara, Bandung.

Kartono Kartini, 1998, Pemimpin dan Kepemimpinan, Grafindo, Jakarta.

Kodoatie, Robert \& Basoeki,M, Kajian Undangundang Sumber Daya Air, Andi, Yogyakarta

Kumorotomo, Wahyudi, 1995, Etika Administrasi Negara, Raja Grafindo, Jakarta.

Lembaga Administrasi Negara LAN, 2007, Jakarta

Leavitt, Harold, 1986, Organisasi dan Manajemen, Erlangga, Jakarta.

Nasucha, Chaizi, 2004, Reformasi Administrasi Publik Teori dan Praktik, Grasindo, Jakarta

Nawawi, Hadarin 1992, Metode Penelitian Bidang Sosial, Press, Yogyakarta.

Metro dalam angka, Metro City in Figures, 2013, BPS Kota Metro

Pasolong, Harbani, 2013, Teori Administrasi Publik, Alfabeta, Bandung.

Osborn, David \& Gaebler, Ted, 1992, Mewirausahakan Birokrasi, Transformasi Semangat Wira Usaha ke Dalam Sektor Publik. PPM, Jakarta.

Osborn, David \& Plastrik, 1997, Memangkas Birokrasi, Lima Strategi Menuju Pemerintahan
Wira Usaha,PPM, Jakarta.

ISSN : 2614-2570

Pareek Udai, 1996, Perilaku Organisasi, Pedoman ke arah Pamahaman Proses Komunikasi Antar Pribadi dan Motivasi Kerja, Pustaka Binawan Pressindo, Jakarta.

Pinno, E \& Wittermans, 1996, Kamus Lengkap Bahasa Indonesia-Inggris, Inggris-Indonesia, Jakarta

Prawiro Sentono, Suyadi, 1999, Manajemen Sumber Daya Manusia; Kebijakan Kinerja Karyawan Kiat Membangun Organisasi Kompetitif Menjelang Perdagangan Bebas Dunia, BPFE, Yogyakarta

Rangkuti, Freddy, 2008, Measuring Customer Satisfaction,Gramedia Pusataka Utama, Jakarta

Riwukaho, Yoseph, 1988, Prospek Otonomi Daerah di Indonesia,Rajawali Press, Jakarta.

Santoso, Singgih, 2003, Penuntun Latihan SPSS, EleksMedia Komputindo, Jakarta.

Singarimbun, Masri \& Effendi, Sofyan, 1989, Metode Penelitian Survey, LP3ES, Jakarta.

Soetopo, 1999, Pelayanan Prima, LAN-RI, Jakarta Steers, Richard, (1980), Organizational Effektiveness ;

A Behavioral View, Good Year Publishing

Company Inc, Santa Monica

Sugiono, 1999, Metode Penelitian administrasi, Alfabeta, Bandung

Sugiyono, 2013, Metode Penelitian Pendidikan (Pendekatan Kuantitatif, Kualitatif dan R\&D, Alfabeta, Bandung

Suryadi, DS, 2002, Faktor-Faktor Yang Mempengaruhi Kepuasan Customer PDAM Kota Magelang, Tesis Tidak dipublikasikan, Magister Manajemen Universitas Soedirman, Purwokerto.

Sutrisno, Edy, 2010, Budaya Organisasi, Kencana Prenada Media Group,Jakarta

Tjandra, Riawan,2005, Peningkatan Kapasitas Pemerintah Daerah dalam Pelayanan Publik, Pembaruan, Yogyakarta

Thoha, Miftah, 1999, Perilaku Organisasi, Rajawali, Jakarta

Rajawali, Jakarta

Pembinaan Organisasi,

1999, Pembinaan

2008, Ilmu Administrasi Publik

Kontemporer, Kencana Prenada Media Group, Jakarta

Tresiana, Novita, 2013, Metode Penelitian Kualitatif, Penerbit Lembaga Penelitian Universitas Lampung, Bandar Lampung.

Trogen, P.C. 2004. Public Goods. Handbook of Public Sector Economics : 198-205.

Wahab, Solichin, 2008, Pengantar Analisis Kebijakan 
Publik, UMM Press, Malang

Wood, Ivonne, 2009, Layanan Pelanggan, Graha Ilmu,Yogyakarta 